



\section{Encontrar la forma. Naturaleza y ser humano en las escuelas de Hans Scharoun}

Finding the Form. Nature and Human Being

in Hans Scharoun's Schools

\section{José de Coca Leicher}

Escuela Técnica Superior de Arquitectura, Universidad Politécnica de Madrid

Traducción Translation Edward Twait, José de Coca

\section{Palabras clave Keywords}

Scharoun, Darmstadt, escuelas, arquitectura orgánica, Formfindung

Scharoun, Darmstadt, schools, organic architecture, Formfindung

\section{Resumen}

Casi setenta años después de su aparición revisamos el proyecto de la Escuela de Darmstadt y la posterior materialización en las Escuelas de Lünen y Marl, profundizando en las claves del pensamiento orgánico de Hans Scharoun. A partir de su implantación, la escuela es un agregado de células que a su vez generan el barrio y la ciudad. El método proyectual deductivo de la forma o Formfindung incorpora con aparente naturalidad los condicionantes sociales, pedagógicos, constructivos y económicos, educando e integrando orgánicamente al individuo en la sociedad, generando una arquitectura con vigencia y proyección futura. Concluimos con la actualidad y el aprecio social de las escuelas de Scharoun, ambas en uso y recientemente renovadas adaptándolas a las necesidades actuales, que perviven gracias al empeño comunitario de los habitantes de ambas ciudades.

\section{Abstract}

Almost seventy years after its appearance, we review the project of the School of Darmstadt and its subsequent materialization in the Schools of Lünen and Marl, examining in depth the keys of Hans Scharoun's organic thinking. From its implementation, the school is an aggregate of cells generating in its turn the neighborhood and the city. The projective method, deductive of the form or Formfindung, incorporates the social, pedagogical, constructive and economic requirements with apparent simplicity, educating and organically integrating the individual into society, generating an architecture with validity and future projection. We conclude with the present time and the social appreciation of the Scharoun schools, both of which are in use and have been recently renovated adapting them to current needs, and which persist thanks to the community efforts of the inhabitants of both cities. 
"Ich weiss, aber die Schule wird auch so ihren Weg machen".

"Lo sé, pero así también la escuela recorrerá su camino". (1)

Mensch und Raum. Darmstadt y Scharoun en el contexto político y social. En 1951, después de la Segunda Guerra Mundial, Darmstadt fue la ciudad escogida para el congreso con el lema 'Mensch und Raum', (2) celebrándose en la Mätildenhöhe, sede cincuenta años antes, de la famosa exposición de la secesión. El debate se dirigió a los ciudadanos, restando protagonismo a los partidos políticos, propiciando el dialogo directo en un contexto de ruina física, daño moral, la ocupación aliada, la fractura de Alemania y la incipiente Guerra Fría. En las sesiones, once equipos presentaron propuestas para diferentes edificios públicos. Etiquetados por Otto Bartning, participaron los arquitectos 'tradicionalistas': P. Bonatz, P. Grund y E. Neufert; los 'modernos': H. Scharoun, M. Taut, R. Schwartz, F. Schuster y H. Schwippert, y los 'jóvenes': E. Eierman, S. Ruf, Mäckler y Giefer. Scharoun presentó su proyecto de escuela primaria, que no se realizó, pero en el que ya aparecían los principios y el método proyectual desarrollados posteriormente en las Escuelas de Lünen y Marl.

Los filósofos Martín Heidegger y José Ortega y Gasset, y los sociólogos Alfred Weber y Dolf Sternberger aportaron importantes ideales para la reconstrucción. Heidegger leyó 'Construir, habitar, pensar', (3) una dicotomía entre construir y habitar advirtiendo: "[...] los mortales tienen que volver a buscar la esencia del habitar [...] tienen primero que aprender a habitar", criticando la incapacidad del funcionalismo para crear lugares adecuados al ser humano. Ortega planteó "el mito del hombre allende la técnica" (4) oponiendo técnica y naturaleza, diciendo: "construimos porque estamos insatisfechos", la técnica provoca la frustración de "un gigantesco aparato ortopédico", proponiendo un mayor acercamiento del ser humano a la dimensión natural de su existencia.

Poco antes, Scharoun, como arquitecto asesor para la vivienda, había dirigido el Kollectivplan para reconstruir el Gran Berlín. En 1946 obtiene una cátedra de urbanismo en la TU de Berlín, siendo nombrado en 1947 director del Instituto de la Construcción de la Academia de Ciencias de Berlín. Atrás, los años difíci-

\footnotetext{
"Ich weiss, aber die Schule wird auch so ihren Weg machen". (1)

"I know, but this way the school will also travel its own road."
}

Mensch und Raum. Darmstadt and Scharoun in the Political and Social Context. In 1951, after the Second World War, Darmstadt was the city chosen for the congress with the theme 'Mensch und Raum', (2) being held in the Mätildenhöhe; headquarters, fifty years before, of the famous statement of secession. The debate was directed towards the citizens, taking away the leading role from the political parties, favoring direct dialogue in the context of physical ruin, moral damage, the Allied occupation, the breakup of Germany and the incipient Cold War. During the sessions, eleven teams put forward proposals for different public buildings. Labeled by Otto Bartning, there took part the 'traditionalist' architects: P. Bonatz, P. Grund and E. Neufert; the 'modern': H. Scharoun, M. Taut, R. Schwartz, F. Schuster and H. Schwippert, and the 'youth': E. Eierman, S. Ruf, Mäckler and Giefer. Scharoun presented his primary school project which was not carried out, but in which already appeared the principles and the projective method developed later in the Schools of Lünen and Marl.

The philosophers Martin Heidegger and José Ortega y Gasset, and the sociologists Alfred Weber and Dolf Sternberger provided important ideals for the reconstruction. Heidegger read 'Building Dwelling Thinking', (3) a dichotomy between to build and to dwell and also cautioning: "[...] mortal men have to search again for the essence of dwelling [...] first, they have to learn to dwell”, criticizing Functionalism's inability to create spaces appropriate for human beings. Ortega raised "The myth of man beyond technique" (4) opposing technique and nature, saying: "we build because we are dis- 
les, la persecución nazi de la arquitectura moderna, la pérdida de su cátedra en Breslau y la prohibición de encargos públicos subsistiendo con trabajos privados, rechazando, como Hugo Haring, abandonar Alemania. Un periodo introspectivo, realizando viviendas obligadamente tradicionales, pero explorando el espacio interior y su relación orgánica con el paisaje. Al ser imposible construir había imaginado potentes utopías, ensayos previos de los proyectos posteriores.

\section{El proyecto de Darmstadt (1951)}

LOS PANELES Y LA LÓGICA DEL PROYECTO. Darmstadt es realizado en equipo; (5) el proyecto incorpora metodologías del Kollectivplan, analizando la forma urbana mediante los dibujos evolutivos del Nest (nido). (6) Para Scharoun, la cuadrícula neoclásica violenta el paisaje del valle, restaurándose a finales del siglo XIx la organicidad medieval al surgir células-nido diferenciadas -en forma y uso- que enriquecen la monotonía urbana, mostrándose la Matildenhöhe como "un ejemplo singular de forma anidada". La escuela se sitúa en el parque Rudolf-Müller a orillas del Grosser Woog. El solar, parcialmente arbolado y paralelo a la Landgraf-Georg-Straße, asciende desde el estanque al este y es flanqueado al sur por un arroyo, quedando la parte más elevada al oeste, divisándose la torre de la Matildenhöhe, el castillo y los baños Jugendstil, la Stadtkirche y el mercado. (Fig. 1) La importancia que da a estas piezas simbólicas, ubicando el mirador en el punto de acceso, muestra la influencia en Scharoun de las ideas de Camilo Sitte, influyente entre los arquitectos de la Matildenhöhe (7) y criticado por los urbanistas funcionalistas, especialmente Le Corbusier. En el panel se valoran gráficamente los edificios limítrofes y en azul, el arroyo y el estanque. A los pies, la entrada con el bloque de despachos y la plataforma de acceso correspondiente al punto más alto, destacado con el mirador con cuatro árboles, mostrando también la conexión del arroyo con el albergue juvenil y el Grosser Woog.

La maqueta muestra formas cambiantes a lo largo de un eje quebrado definido por las piezas altas (dominante). Rudolf Schwarz había caricaturizado el proyecto como un Eisenbahnunglück (8) o accidente ferroviario (qui-

satisfied", technique provokes the frustration of "a gigantic orthopaedic device", and he proposes a greater approach of the human being to the natural dimension of his existence. Shortly before, as advising architect for housing, Scharoun had directed the Kollectivplan to rebuild Greater Berlin. In 1946 he obtains an urban development professorship at Berlin Technical University and in 1947 is appointed director of the Institute of Construction of the Berlin Academy of Sciences. Previously, during the difficult years, the Nazi persecution of modern architecture, the loss of his professorship in Breslau and forbidden to carry out public commissions, he survived on private works and refused, like Hugo Haring, to leave Germany. It was an introspective period when he undertook houses which were by obligation traditional but exploring the interior space and its organic relationship with the landscape. As it was impossible for him to build, he had imagined powerful Utopias, previous tests for the later projects.

The Darmstadt Project (1951)

THE PANELS AND THE LOGIC OF THE PRoject. Darmstadt is carried out in a team, (5) and the project incorporates methodologies of the Kollectivplan, analysing the urban form by means of the evolutionary drawings of the Nest. (6) For Scharoun, the neoclassical squares distort the landscape of the valley, the medieval organic quality being restored at the end of the 19th Century when differentiated nest-cells emerge - in both form and use - which enrich the urban monotony, showing the Matildenhöhe as "an outstanding example of sheltered form". The school is located in the RudolfMüller park on the banks of the Grosser Woog. The site, partially wooded, parallel to the Landgraf-Georg-Strasse, ascends 


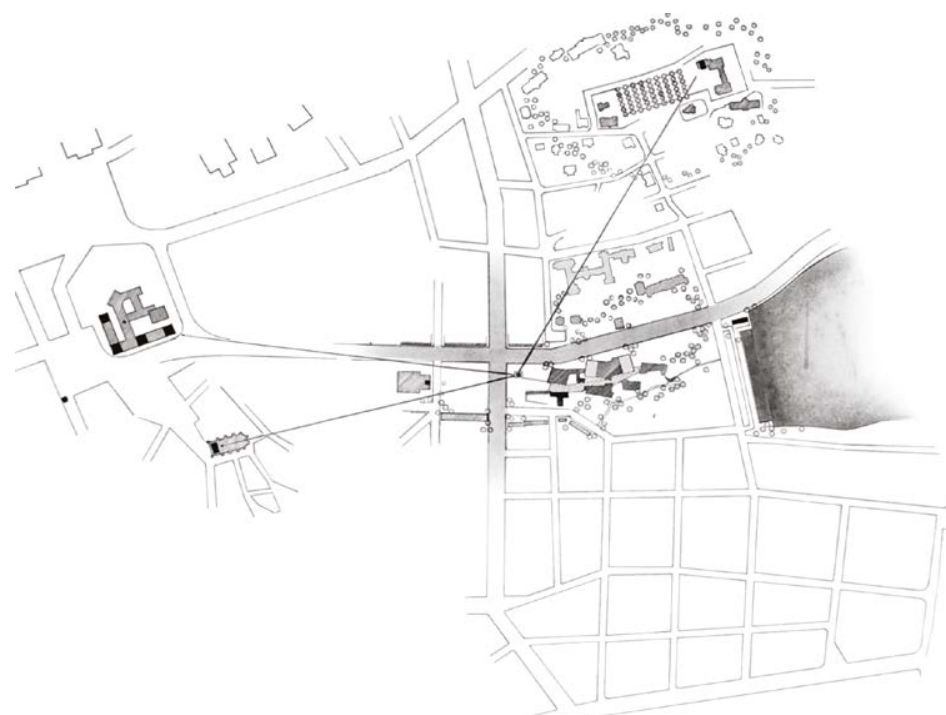

zás recordase la destrucción de Alemania). Paul Bonatz criticó la relación función-forma de un proyecto zerdacht o despedazado mentalmente por Scharoun, totalmente despreocupado por su apariencia. (9) Es un collage de formas que recuerda a los Merzbilder de K. Schwitters. Todo este 'caos', pueblo cubista o Kasbah crecido espontáneamente tiene una lógica interna, un ideal generador para "encontrar la forma", veamos cual. (Fig. 2)

En 1960, en la XII Trienal de Milán, Scharoun enuncia los principios sociales y democráticos de sus escuelas: "La misión primordial de la educación es la integración del individuo en la sociedad, su desarrollo hacia la responsabilidad personal — con la meta de un crecimiento cualitativo-, para que así, una comunidad surja del carácter potenciador y no aditivo. Se trata con ello no sólo de aumentar el conocimiento, sino de provocar las experiencias y la toma de
Fig. 1. Darmstadt. Relaciones urbanas y estéticas. Fragmento de panel, 1951. Schirren, Mathias: 'Wind und Wasser, Raum und Zeit', 2014.

from the pond to the east and is flanked to the south by a stream, the highest part standing to the west, distinguishing the Matildenhöhe tower, the castle and the Jungendstil baths, the Stadtkirche and the market. (Fig. 1)

The importance given to these symbolic pieces, situating the viewpoint at the place of access, shows the influence of the ideas of Camilo Sitte upon Scharoun, influential also among the architects of the Matildenhöhe (7) and criticized by functionalist urban developers, particularly Le Corbusier. In the panel, the bordering buildings are appraised graphically and in blue the stream and the pond. At the foot, the entrance with the office block and the access platform corresponding to the highest point, emphasized with the overlook with four trees, also showing the connection of the stream with the youth hostel and the Grosser Woog.

The scale model shows changing forms along a zigzag axis defined by the (dominant) high pieces. Rudolf Schwarz had caricaturized the project as an Eisenbahnglück (8) or railway accident (perhaps remembering the destruction of Germany). Paul Bonatz criticized the function-form relationship of a zerdacht project or torn apart mentally by Scharoun, totally unconcerned by its appearance. (9) It is a collage of forms which recalls the Merzbilder of K. Schwitters. All this 'chaos', cubist village or Kasbah grown spontaneously has an internal logic, a generating ideal in order to "find the form", which we will now see. (Fig. 2)

In 1960, at the XII Triennial of Milan, Scharoun declares the social and democratic principles of his schools: "The fundamental mission of education is the integration of the individual in society, his development towards personal responsibility — with the goal of qualitative growth - , so that in this way a community arises from the enhancing, not additive, 
conciencia, para que el individuo pueda encontrar el verdadero contacto con la vida pública y la relación con la comunidad política. [...] Así, un edificio escolar no debería ser un símbolo del poder político o el resultado de una perfección técnica o artística. Como cualquier otro edificio, una escuela debería producir una imagen que exprese el principio universal de la democracia”. (10)

El agregado de células educacionales diferenciadas formará un conjunto mayor que a su vez es una célula activa integrada en la estructura urbana y social, una nueva expresión de los principios del Kolectivplan. El panel a escala 1/200 muestra en gris el itinerario principal conectando las célulasaula, en azul el arroyo y una lámina de agua, inadvertida en otros estudios. (11) La plaza de acceso, en forma de embudo, queda definida a la derecha por la vivienda del portero, el huerto y unos establos; a la izquierda, el testero ciego y la cubierta curva de la sala de actos dirige la vista hacia la puerta principal. Igualmente, el bloque de cuatro plantas con los despachos y administración, alineado con el itinerario principal es mostrado en escorzo en la perspectiva de Sergius Ruegenberg . La escuela expresa su fuerte identidad moderna: bloque-torre, cubierta curva con lucernario y cuerpos bajos y horizontales como 'elementos dominantes' hacia la calle y la ciudad.

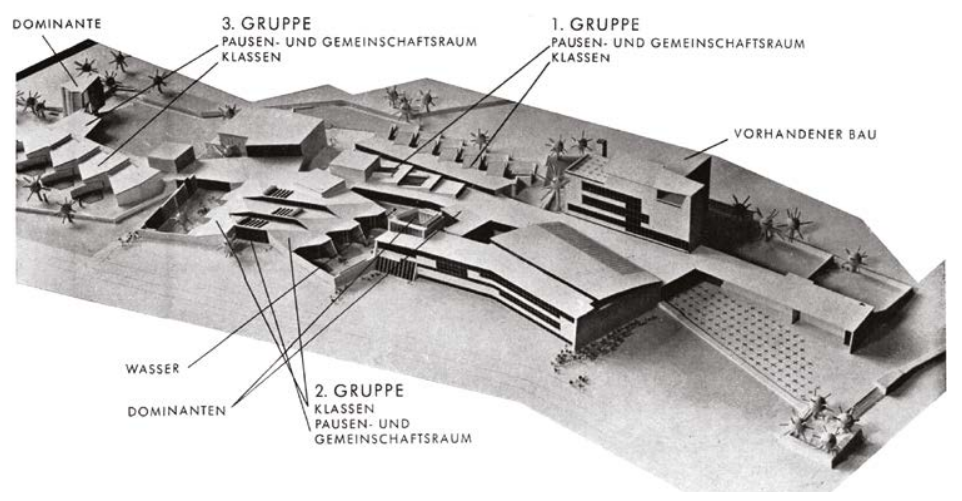

Fig. 2. Fotografía de la maqueta publicada. Bartning, Otto: 'Mensch und Raum', 1951.

nature. It is a question of not only increasing knowledge but to lead to experiences and to become aware, so that the individual can find real contact with public life and relationship with the political community. [...] Thus, a school building should not be a symbol of political power nor the result of technical or artistic perfection. Like any other building, a school should generate an image which expresses the universal principle of democracy". (10)

The aggregate of differentiated educational cells will form a greater whole, which in turn is an active cell integrated in the urban and social structure, a new expression of the principles of the Kolectivplan. The panel at 1/200 scale shows the main route connecting the classroom-cells in grey, with the stream and a sheet of water in blue, unnoticed in other studies. (11) The access square in the shape of a funnel is defined on the right by the caretaker's house, the orchard and a few cowsheds: to the left, the blind face and curved roof of the assembly hall direct the view towards the main door. Likewise, the four-floor office and administration block, which aligned with the main route is shown foreshortened in the Sergius Ruegenberg perspective. (12) The school expresses a strong modern identity: tower block, curved roof with skylight and low horizontal bodies as 'dominant elements' towards the street and the city.

The landscape-itinerary symbolizes the route of life and learning. The classrooms are grouped in packets Schulschaften (neighboring classrooms), extending the Nachbarschaft urban concept (neighborhood and reciprocity) expanded on by Scharoun (13) to the three educational levels. Space, light, color and function are defined in line with the degree of maturity, from the 'vegetative' to the 'spiritual', accompanying the biological development of the child, a real Utopia in harsh postwar 
El itinerario-paisaje simboliza el itinerario vital y de aprendizaje. Las aulas se agrupan en paquetes Schulschaften (aulas vecinales), extendiendo el concepto urbano Nachbarschaft (vecindad y reciprocidad) extendido por Scharoun (13) a los tres niveles formativos. El espacio, la luz, el color y la función se definen según el grado de madurez, desde lo 'vegetativo' a lo 'espiritual', acompañando la evolución biológica del niño, una verdadera utopía en la durísima postguerra Alemana. (14) El primer assemblage lo constituye 'la gran sala abierta', el continuo espacial que forman la entrada, las gradas abiertas del salón de actos y las taquillas del bloque administrativo. El segundo tramo del pasillo o 'pasaje del encuentro' se abre hacia la sombra de un árbol y a la izquierda, a un patio con una lámina de agua y otro pequeño árbol. Una pasarela escalonada separa funcional y visualmente la zona de talleres y manualidades de la capilla, abierta al norte y utilizada como aula de religión, marcando el siguiente tramo con un pasillo estrecho y alargado flanqueado a la derecha por las aulas del grupo A; a la izquierda por la lámina de agua y al fondo por el jardín del grupo B. Comienza 'el recinto secreto', un ámbito privado señalado con dos torres, que atravesamos como el foso de una pequeña ciudadela. (Fig. 3)

LOS TIPOS DE AULA. El nivel A, 'grupo del juego' corresponde a la etapa elemental de seis a nueve años (entre primero y tercero de primaria). Extensión de la casa familiar donde, mediante el juego, se inicia el comportamiento social. El crecimiento corporal y espiritual necesita luz y sol, las aulas, orientadas al sur, se forman a partir de un cuadrado interior con una gran pared para dibujar, extendida en otro cuerpo iluminado cenitalmente desde el este. A su vez, esta pieza genera un patio de luz, estrecho y alargado que sale a un jardín con pérgola y murete bajo abierto a una pradera. El contacto con la naturaleza se simboliza con una vaca tumbada en el patio, observada por niños. (Fig. 4)

El nivel B, 'grupo de trabajo' es la etapa media de nueve a doce años (entre cuarto y sexto de primaria). Introducir la disciplina y la atención orientadas hacia el 'aprendizaje serio'; el espacio debe 'afianzar y reforzar', por lo que se materializa en dos unidades cuadradas de tres aulas cada una, divididas longitudinalmente en tres partes: el aula, su extensión semicubierta y el jar-
Fig. 3. Planta de conjunto con leyenda. Johnes, Peter B.: 'Hans Scharoun eine Monografie' (traducción del autor), 1979.

1. Nivel superior, 2 . Nivel medio, 3. Nivel elemental, 4. Camino del encuentro, 5. Gimnasio, 6 Puerta y ropero con WCs, 7 . Sala de profesores y administración, 8. Vivienda del portero, 9. Lámina de agua, 10. Salón de actos, 11. Aulas de arte y talleres, 12. Capilla, 13. Biblioteca, 14. Sala cósmica, 15. Patio de recreo.

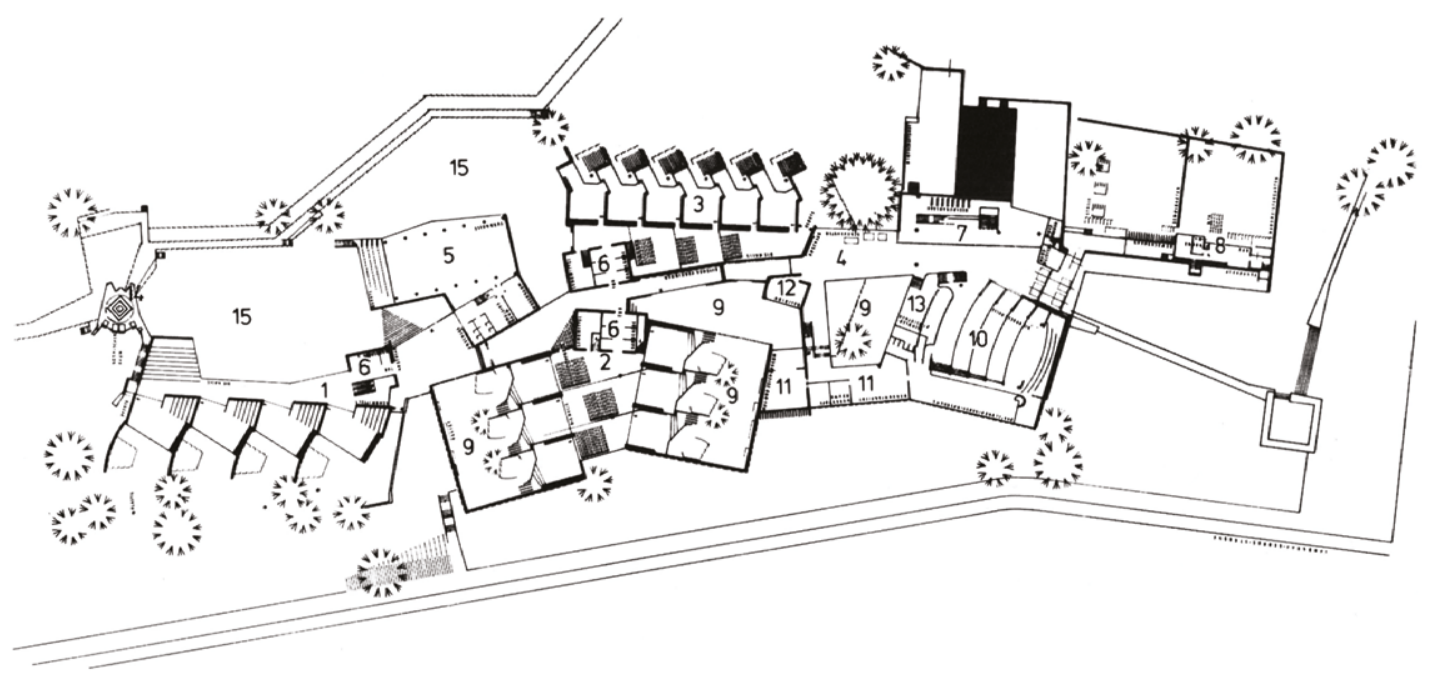




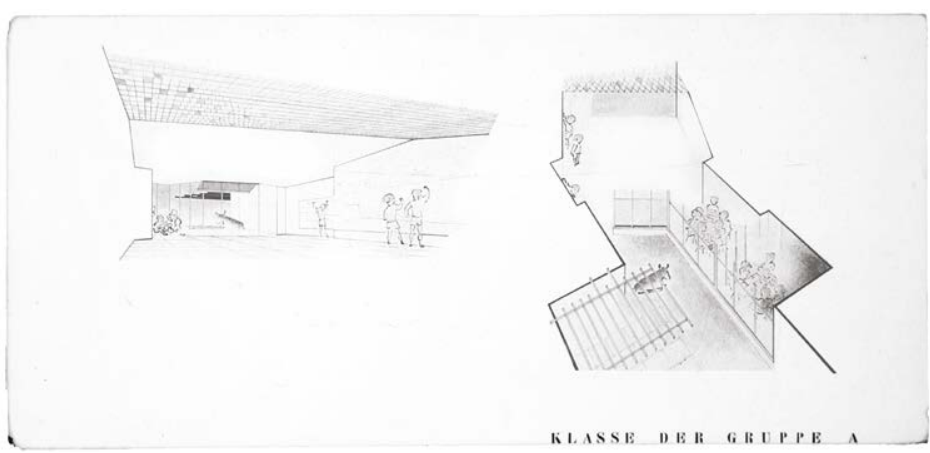

dín o aula exterior. La luz solar directa distraería y las aulas se orientan en la dirección del itinerario principal, al este y al oeste, obteniéndose la luz difusa del norte a través de un pliegue en la cubierta.

El nivel C, 'el individuo y el grupo' en la etapa superior de doce a catorce años (primero y segundo de secundaria), obtenían el graduado escolar pudiendo cursar bachillerato. Formados en la toma de conciencia, la responsabilidad social, la autodisciplina y el sentido común. Las aulas, con igual esquema tripartito, son más abiertas y menos rígidas, con iluminación al norte, como en los talleres de los artistas. (Fig. 5)

LOS ESPACiOS COMUNES. El acceso a las aulas sólo es posible por las 'torres' de aseos y roperos, elementos 'dominantes' que ordenan el conglomerado. Dan acceso a una antesala, espacio muy característico en Scharoun, adaptado a cada proyecto. Es diferente según el tipo de aula, sirviendo de paso y encuentro para actividades conjuntas, apartadas de la circulación general. Cada 'nido' funciona como una 'isla'; en el tipo A, el espacio común es estrecho, alargado, con cubierta escalonada iluminada naturalmente desde el oeste y claraboyas con oscurecimiento. En las de tipo B el esquema es idéntico, con proporción más ancha y escalonamiento hacia el norte de lucernarios y claraboyas. Las torres están enfrentadas a ambos lados del pasillo, al igual que
Fig. 4. Clase del nivel A. Panel de la exposición, 1951. Schirren, Mathias: 'Wind und Wasser, Raum und Zeit, 2014.

Germany. (14) The first assemblage is made up of 'the great open hall', the spatial continuum formed by the entrance, the open tiers of the assembly hall and the offices of the administrative block. The second stretch of the corridor or 'meeting passageway' opens towards the shade of a tree and to the left to a patio with a sheet of water and another small tree. A stepped footbridge separates the area of workshops and handicrafts functionally and visually from the chapel, open to the north and used as the religion classroom, marking the following stretch with a narrow and prolonged corridor, flanked to the right by the group A schoolrooms and to the left by the sheet of water and then to the bottom, the garden of group B. 'The secret enclosure' begins, a private area marked by two towers which we pass through like the moat of a small fortress. (Fig. 3)

THE TYPES OF CLASSROOM. Level A, 'play group' corresponds to the elementary stage from six to nine years old (between first and third year of the elementary school). It is the extension of the family home where, through play, social behavior begins. Bodily and spiritual growth require light and sun, the classrooms, facing the south, are formed from an interior square with a large wall for drawing, extended into another body illuminated from the highest point from the east. In turn, this piece generates a narrow and prolonged patio of light which leads to a garden with a pergola and a small low wall open to a meadow. Contact with nature is symbolized with a cow lying in the patio and observed by children. (Fig. 4)

Level B, 'working group' is the middle stage from nine to twelve years old (fourth and sixth of the elementary school). It is to introduce discipline and attention oriented towards 'serious learning', the space should 'support and strengthen' and so is materialized in two square units of three classrooms each and are divided lengthways in three parts: the classroom, its 

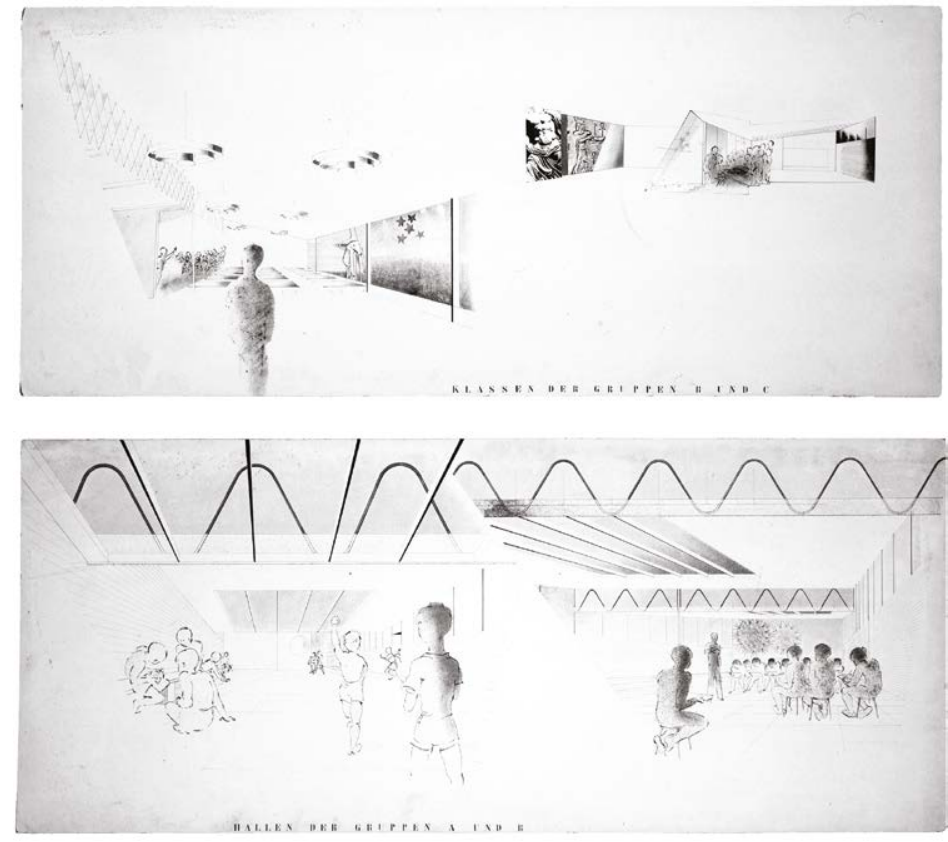

el acceso a los espacios comunes que conectan con los patios: los de tipo A, directamente al patio alrededor del gimnasio compartido con los mayores e igualmente los de tipo $\mathrm{B}$, atravesando el pasillo a ambos lados del gimnasio. (Fig. 6) Pasado el gimnasio, al final del recorrido y a través de la última torre, se accede al espacio común de las aulas tipo $\mathrm{C}$, un pasillo con una pequeña sala en graderío que da acceso a una enigmática pieza de remate.

LA SALA Cósmica. Es un santuario que rememora la Stadtkrone expresionista y la pieza central de la escuela de Bruno Taut en Folkwang, (15) Haus der festlichen Andacht (Casa de la Oración). Centrada con el patio del gimnasio, a la
Fig. 5. Clases de nivel B y C. Panel de la exposición, 1951. Schirren, Mathias: 'Wind und Wasser, Raum und Zeit, 2014.

Fig. 6. Antesalas niveles A y B. Panel de la exposición, 1951. Schirren, Mathias: 'Wind und Wasser, Raum und Zeit, 2014.

half-covered extension and the garden or outdoor classroom. Direct sunlight would distract and the classrooms face the direction of the main route, to the east and to the west, securing diffused light from the north through a fold in the roof.

Level C, 'the individual and the group' is the higher stage from twelve to forteen years old (first and second years of the secondary school), graduating and being able to take High School studies. The children are taught to become aware, to have social responsibility, self-discipline and common sense. The classrooms, with the same tripartite scheme, are more open and less rigid, with illumination to the north, as in an artist's studio. (Fig. 5)

THE COMMON SPACES. Access to the classrooms is only possible through the 'towers' of toilets and clothes closets, 'dominant' elements which put the conglomerate in order. They give access to an entrance hall, a space which was very characteristic of Scharoun and adapted to each project. It is different depending on the type of classroom, serving as a passing and meeting place for joint activities and separated from the general movement of people. Each 'nest' functions as an 'island'. In type A, the common space is narrow and prolonged, with a stepped roof illuminated naturally from the west and skylights with darkening. In those of type B, the scheme is identical with a wider proportion and a stepping array of skylights towards the north. The towers are face to face on both sides of the corridor, likewise the access to the common spaces which connect with the patios: those of type A, directly to the patio around the gymnasium shared with the older students and in the same way, those of type B, passing through the corridor at both sides of the gymnasium. (Fig. 6) Passing the gymnasium, at the end of the route and, going through the last tower 
izquierda del eje principal y elevada sobre cuatro pantallas, se accede a ella por unas escaleras. Su forma de flecha sigue el eje Norte-Sur, con fachadas opacas y quebradas en forma de troneras, mientras que al Este y al Oeste está completamente acristalada, siendo el interior visible desde el patio y el estanque. El suelo es circular, con un cuadrado girado con los vértices señalando los puntos cardinales, formando tres gradas para unos cuarenta alumnos. La pared Norte tiene seis planos desfasados por las troneras, con fragmentos de textos alegóricos a las estaciones de L. Uhland, J. W. Goethe y F. Hebbel, situándose en la parte central la segunda y la cuarta estrofa del poema 'Lebenslauf de F. Hölderling y varias estrofas del poema 'Sprich aus der Ferne' de C. Brentano. En sección recuerda al cáliz de una flor, por la que según las estaciones, entran los rayos del sol iluminando los poemas. La sala cósmica, lugar de introspección para los alumnos mayores, (Fig. 7) recuerda los diseños expresionistas de Scharoun: la sala del Centro Cultural en Geselkirchen y su desarrollo en las escuelas y la Filarmónica.

ANTECEDENTES DE DARMSTAD. Soluciones parecidas a las aulas-patio son ensayadas en las viviendas de Friedrichshaim y el invernadero de la Casa Schminke. La relación entre interior y patio se investiga profundizando en las casas de los años treinta y cuarenta, especialmente la Casa Baensch (1935), la Casa Moll (1936-37) y la Casa Moller (1937). Otras influencias (16) son los modelos urbanísticos de L. Hilbersheimer, Hugo Haring y el famoso libro Das neue Schulhaus de Alfred Roth, texto de los CIAM con soluciones funcionales y espaciales; entre otras, aulas con espacios complementarios y colectivos como las salas de música, con ejemplos como la escuela de E. Beaudonin y M. Lods (1935-36), muy influyentes en Darmstadt. Un último apunte es la casa patio china, (17) la relación entre arquitectura y naturaleza es debida al colaborador Chen Kuen Lee, expresada en la axonometría del concurso: un bello y abstracto dibujo combina diferentes elementos: la arquitectura, el agua, las nubes, el sol y el paso del tiempo como temas de proyecto que interactúan para encontrar la forma final.

La Escuela de Lünen (1956-62). La oportunidad de confirmar estas ideas llega en 1956 con la Escuela-Gimnasio femenina en Lünen, pequeña ciudad al
Fig. 7. La sala cósmica. Panel de la exposición, 1951. Schirren, Mathias: 'Wind und Wasser, Raum und Zeit, 2014.

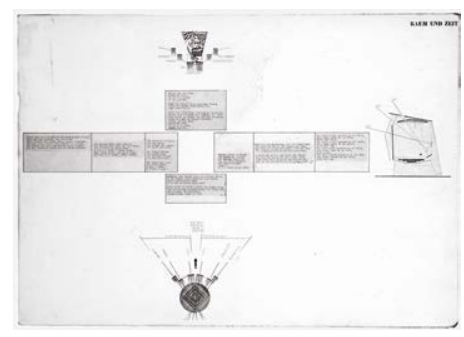

accesses the common space of type C classrooms, a corridor with a small tiered hall gives access to an enigmatic finishing-touch piece.

THE COSMIC HALL. It is a shrine recalling the expressionist Stadtkrone and the central piece and the school of Bruno Taut in Folkwang (15) Haus der festlichen Andacht (House of Prayer). Centered with the patio of the gymnasium, to the left of the main axis and raised over four screens, access is gained along a staircase. Its arrow shape follows the north-south axis, with opaque and broken façades in the shape of small windows, whereas to the east and to the west it is completely glazed and making the interior visible from the patio and the pond. The floor is circular with a square rotated with the vertices signaling the cardinal points forming three tiers for some forty pupils. The north wall has six planes which are put out of phase by the small windows with fragments of texts allegorical to the seasons by L. Uhland, J. W. Goethe and F. Hebbel, placing in the central part the second and the forth verse of the 'Lebenslauf poem by F. Hölderling and several verses of the 'Sprich aus der Ferne' poem by C. Bretano. In section, it recalls the calyx of a flower, by which, depending on the seasons, the rays of sunlight come in illuminating the poems. The cosmic hall, a place of introspection for the older pupils, (Fig. 7) recalls Scharoun's expressionist designs, the hall of the Cultural Center in Geselkirchen, its development in the schools and the Philharmonie.

THE BACKGROUND TO DARMSTAD. Similar solutions to the patio-classrooms are tried out in the houses of Friedrichshaim and the Schminke House greenhouse. The relationship between interior and patio is examined in depth in the houses of the 30's and 40's, especially the Baensch House (1935), Moll House (1936-37) and Moller House (1937). Other influences (16) are 
norte del industrial Dortmund. El lugar se vuelve a incorporar al proyecto, la Holtgrevenstrasse, anillo verde de la antigua muralla, cae hacia el sur y es la base de la colina rematada por una torre neogótica. El conjunto forma un frente cerrado y arqueado restituyendo la muralla. Al sur, forma dos patios: en el mayor se dispone la gran sala poligonal en forma de pentágono abierto, mientras que el segundo es estrecho y discurre entre los dos peines de aulas, separando el nivel elemental del medio. La entrada se sitúa al oeste, detrás de

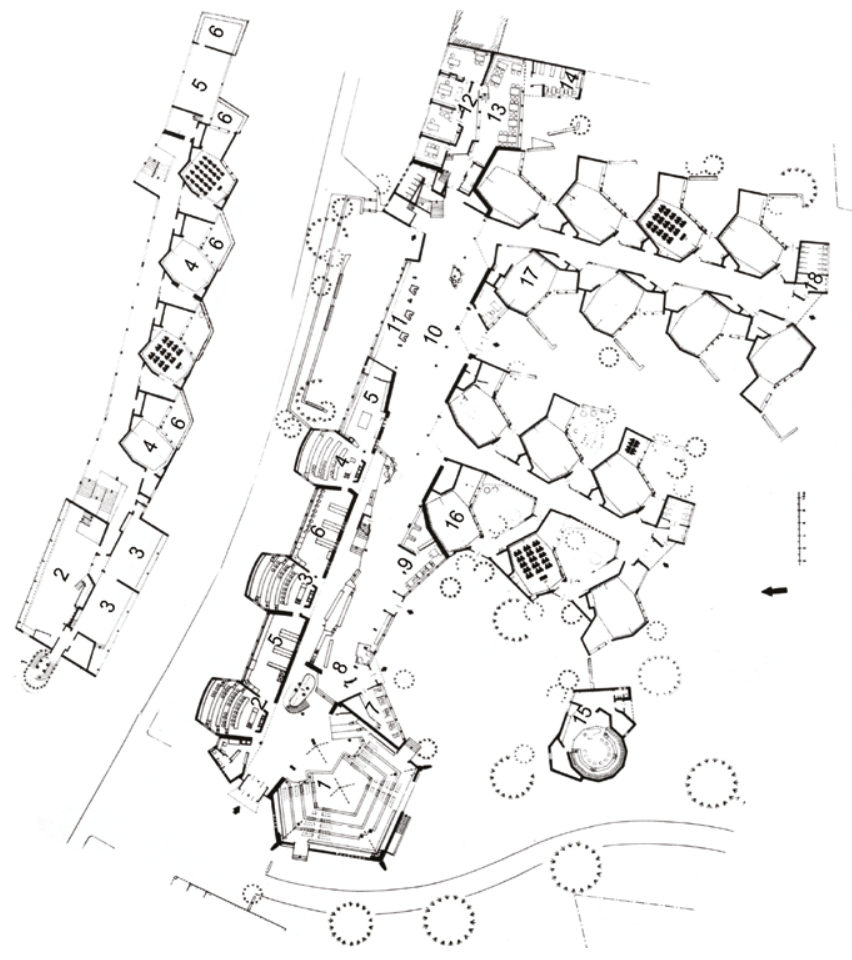

Fig. 8. Planta baja y primera de la escuela de Lünen, 1958. Johnes, Peter B.: 'Hans Scharoun eine Monografie' (traducción del autor), 1979. Planta Baja:

1. Gran Aula, 2. Física, 3. Biología, 4. Química,

5. Preparación, 6. Laboratorio, 7. Delegación, 8. Sala de recreo, 9. Biblioteca escolar, 10. Gran sala, 11. Acuario, 12. Profesorado, 13. Sala de profesores, 14. Biblioteca de profesores, 15 . Aula de música (no construida), 16. Nivel elemental, 17. Nivel medio, 18. WCs.

Planta Primera:

1. Escalera, 2. Sala de dibujo, 3. Talleres, 4. Nivel superior, 5. Sala multiuso, 6. Terraza.

the urbanistic models of L. Hilbersheimer, Hugo Haring and the famous book Das neue Schulhaus, by Alfred Roth, text of the CIAM with functional and spatial solutions, among others, classrooms with complementary and collective spaces such as auditoriums, with examples, like the school of E. Beaudonin and M. Lods (1935-36) and which were very influential in Darmstadt. A final note is the Chinese patio house, (17) the relationship between architecture and nature is due to the collaborator Chen Kuen Lee, expressed in the axonometric of the competition: a beautiful and abstract drawing combines different elements: architecture, water, clouds, the sun and the passing of time as project themes which interact to find the final form.

The Lünen School (1956-62). The opportunity to confirm these ides arrives in 1956 with the School-Gymnasium for girls in Lünen, a small city to the north of industrial Dortmund. The place is again incorporated into the project, the Holtgravenstasse, the green ring of the old wall, which lies towards the south and is the base of the hill finished off by a neo-gothic tower. The ensemble forms a closed and arched front restoring the wall. To the south, it forms two patios: in the larger, the great polygonal hall is laid out in the shape of an open pentagon, the second is narrow and flows between the two combs of classrooms separating the elementary and middle levels. The entrance is located to the west, behind the great hall, touching the street and flanked by the body of classrooms with tiers for biology, physics and chemistry alternating the laboratories. To the right is the large patio window where the student delegation is located and the covered playtime area. At this point the ground is terraced, separating the science area from the level of the classrooms and forming a lengthened and diaphanous space which recalls the 'meeting place' in Darmstadt but extended to the whole unit. This great vestibule is diversified with some elements such as the aquariums and above all is the place of convergence of the combs and the vertical communication with the classrooms on the upper level. (Fig. 8) 
la gran sala pegada a la calle y flanqueada por el cuerpo de las aulas con gradas para biología, física y química, intercalando los laboratorios. A la derecha, el ventanal del patio donde se sitúa la delegación de alumnos y la zona de recreo cubierta. En este punto el suelo se escalona, separando la parte de ciencias del nivel de las aulas, formándose un espacio alargado y diáfano que rememora al 'lugar del encuentro' de Darmstadt, pero extendido a todo el conjunto. Este gran vestíbulo se diversifica con algunos elementos, como los acuarios y sobre todo es el lugar de confluencia de los peines y la comunicación vertical con las aulas del nivel superior. (Fig. 8)

El aula-célula es ahora un tipo único que se deforma y gira levemente, garantizando el acomodo de las aulas vecinas y los dos patios mediante racimos de seis y ocho aulas. Se organiza en cuatro partes: el aula poligonal, el nicho de extensión, el espacio de entrada y el patio o aula al aire libre. Para Scharoun la Klasenwohnung o aula-vivienda permite la 'identificación y apropiación' del lugar de aprendizaje. Un heptágono alargado con dos lados abiertos al patio y al nicho, otro al ropero y el resto ciegos. La luz entra por los ventanales del patio, el nicho y una banda estrecha con doble acristalamiento en el perímetro superior, garantizando la luminosidad y acondicionamiento naturales. (Fig. 9) La célula especializada admite múltiples distribuciones interiores: frontal, en círculo o seminario, segregada en aula y nicho, incluso con dos profesores y grupos. Encaja de diversas formas con la célula vecina, con el corredor dando a un patio interior en el nivel elemental, o como una secuencia de entradas escalonadas resueltas mediante un hueco bajo y translúcido en el nivel medio. Respecto a Darmstadt, los baños se independizan por aula desapareciendo la 'torre' y quedando los aseos comunes al final de cada racimo. Los pasillos se tratan mediante tonos progresivos de colores en las viguetas iluminadas naturalmente, en el techo y en los vestíbulos, decorándose estos con murales artísticos.

En planta primera, sobre el cuerpo cerrado y entre las dos escaleras del vestíbulo se sitúan el aula de dibujo hacia la calle, [ver Fig. 8] los talleres hacía el patio grande, manteniendo las cuatro aulas del nivel superior la misma con-

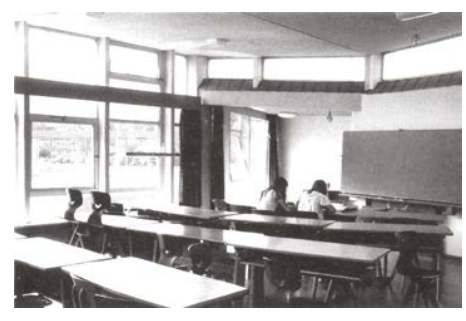

Fig. 9: Escuela de Lünen: aula tipo en los años noventa. Johnes, Peter B.: 'Hans Scharoun', 1995.

The classroom-cell is now a sole model which becomes deformed and rotates slightly guaranteeing the comfortable arrangement of the neighboring classrooms and the two patios, by means of clusters of six and eight classrooms. It is set up in four parts: the polygonal classroom, the extension recess, the entrance space and the patio or open-air classroom. For Scharoun the Klasenwohnung or classroom-dwelling allows the 'identification and appropriation' of the place of learning. A lengthened heptagon with two sides, open to the patio and the recess, another to the clothes closet while the rest are blind. Light enters through the large patio windows, the recess and through a narrow strip with double glazing in the upper perimeter, guaranteeing luminosity and natural conditioning. (Fig. 9) The specialized cell allows multiple interior distributions: frontal, in a circle or seminar, separated in classroom and recess, even with two teachers and groups. It fits in several ways with the neighboring cell, with the corridor leading to an indoor patio at the elementary level, or as a sequence of stepped entrances resolved by means of a low, translucent recess at the middle level. In relation to Darmstadt, the bathrooms become independent by classroom, the 'tower' disappears and the common toilets are at the end of each cluster. The corridors are handled by means of progressive shades of colors on the small beams illuminated naturally, on the roof and in the vestibules, and these decorated with artistic murals.

On the first floor, above the closed body and between the two staircases of the vestibule are located the drawing classroom which is towards the street, [see Fig. 8] the workshops towards the large patio, the four classrooms of the upper level keeping the same configuration except for the patio which is now a terrace. Outwardly, by means of the industrial aspect, Scharoun wishes to express the idea that the girls will receive technical and humanistic training going beyond traditional 'housewife' 
figuración, excepto el patio que ahora es una terraza. Al exterior, mediante el aspecto industrial, Scharoun quiere expresar la idea de que las niñas recibirán una formación técnica y humanística superando la formación tradicional de 'amas de casa', para la que no existía aula específica. Nunca construida, la sala de música decagonal recordaba a la 'sala cósmica', con entrada independiente, como un apéndice del patio y enfrentada al aula grande. [ver Fig. 8]

La Escuela de Marl (1960-68). Marl nace del empeño del alcalde Rudolf Heiland de crear una 'ciudad verde'. Scharoun recibe el encargo en compensación al segundo premio del concurso del ayuntamiento, que ganaron Van de Broeck y Bakema con sus polémicas torres de hormigón. Diseño más evolucionado, consistía inicialmente en un centro comunitario para la ciudad con aulas y enormes vestíbulos. Se reduce, alojando finalmente ocho aulas de nivel elemental, ocho de nivel medio y una para el nivel superior, con un gran aula central (Raum der Mitte) concebida como un graderío en abanico, rodeada de gimnasio, biblioteca, seminario, talleres y generosos espacios comunes. La idea de Darmstadt evoluciona buscando el desarrollo social, cultural y económico de Marl-Drever, en la cuenca del Ruhr, un barrio donde la industria química, la manufactura y la minería son la base económica, siendo la escuela el vehículo para lograr el Qualitästeigerung o crecimiento cualitativo-formativo, el intercambio y el progreso económico. (Fig. 10)

Marl es una estrella irregular alrededor del aula central de mayor altura, formando otra Stadtkrone flanqueada por un parque lineal, que en la primera maqueta (18) era un exterior cubierto con una cúpula que los ciudadanos atravesaban libremente usando las dotaciones comunes, conectadas con cuatro Schulwohnungen o aulas-vivienda, que mediante la sala común formaban las distintas Schulshaften o aulas-vecinales privadas. Entre los brazos de la estrella, alrededor del aula central, se dispone al norte la entrada, accediendo al vestíbulo que conecta los pasillos comunitarios y entre estos, las dotaciones. A la derecha de la entrada, administración, talleres y aulas de ciencias; a la izquierda, gimnasio y vestuarios. Las aulas del nivel medio quedan orientadas al este, situadas sobre las de nivel superior y rodeando al aula central. Las au-

training, and for which there was no specific classroom. Although it was never built, the decagonal music room recalls 'the cosmic hall', with an independent entrance, like an appendage of the patio and facing the large classroom. [see Fig. 8]

The Marl School (1960-68). Marl stems from the determination of the mayor Rudolf Heiland to create 'a green city'. Scharoun receives the commission in compensation for the second prize in the Town Hall competition, which was won by Van de Broeck and Bakema with their polemic concrete towers. It was a more evolved design and consisted initially of a community center for the city with classrooms and enormous vestibules. It is reduced, finally housing eight elementary level classrooms, eight for the middle and one for the upper, with a great central classroom (Raum der Mitte) conceived as a set of tiers in the shape of a fan, surrounded by gymnasium, library, seminar, workshops and generous common spaces. The idea of Darmstadt evolves searching for the social, cultural and economic development of Marl-Drever, in the Ruhr basin, which is a district where the chemical industry, manufacturing and mining are the economic basis and the school is the vehicle to achieve Qualitästeigerung or qualitative-formative growth, interchange and economic progress. (Fig. 10)

Marl is an irregular star around the main hall of greater height, forming another Stadtkrone flanked by a linear park, which in the first scale model (18) was an exterior covered by a dome, which citizens crossed through freely using the common resources, connected by four Schulwohnungen, or classroom-dwellings which by means of the common hall formed the different Schulshaften or private residents-classrooms. Between the branches of the star, around the main hall, the entrance is located to the north, giving access to the vestibule which connects the community corridors and among 


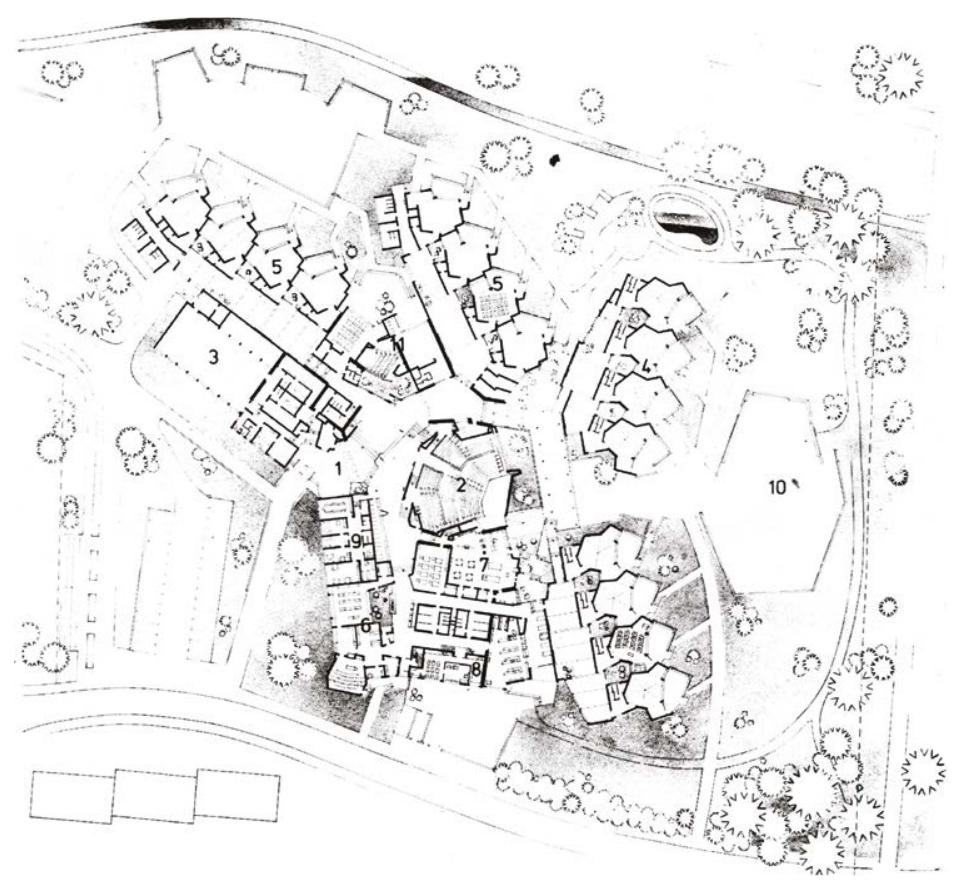

las del nivel elemental se orientan al sur, abiertas a un parque infantil que se prolonga en la lengua de paisaje accediendo al corazón del edificio. (Fig. 11)

Como en Lünen, el esquema aula-nicho-patio es un heptágono, girando el resto de los elementos adecuando su contorno al pasillo, a la orientación o a las condiciones urbanas. En las aulas de nivel elemental la forma alargada es de contorno circular para lograr la máxima flexibilidad docente. Los talleres expresan la industria de Marl con dientes de sierra de perfil curvo, visibles en la entrada, recordando la solución de Darmstadt. Scharoun señala los pro-
Fig. 10: Planta baja de la Escuela de Marl, 1960. Johnes, Peter B.: 'Hans Scharoun eine Monografie' (traducción del autor), 1979.

1. Entrada principal, 2. Gran aula, 3. Gimnasio, 4. Nivel elemental, 5. Nivel medio, 6. Ciencias de la naturaleza, 7. Talleres y trabajos manuales, 8 . Portero, 9. Administración, 10. campo de juegos, 11. Seminarios.

these, the resources. To the right of the entrance are the administration offices, workshops and science classrooms and to the left the gymnasium and dressing rooms. The classrooms at middle level are oriented to the east, located above those of the upper level and surrounding the main hall. The classrooms of the elementary level are oriented to the south and open to a park for children which extends to the tongue of landscape giving access to the heart of the building. (Fig. 11)

As in Lünen, the classroom-recess-patio scheme is a heptagon, rotating the rest of the elements and adapting their shape to the corridor, the orientation or the urban conditions. In the classrooms at elementary level the lengthened form is of circular shape in order to achieve the maximum educational flexibility. The workshops express Marl's industry with sawtooth curved cross section, visible at the entrance and recalling the Darmstadt solution. Scharoun points out the products: cardboard, wood, textile and plastics, and also the character of manufacture, which in some way are reminiscent of the design and production of the Bauhaus. (19) Spatial fluidity and luminosity dominate. The vestibule functions like a covered patio with its large skylight, small observation points with benches, staircases and its extension in the corridors creates variety and spatial dynamism, strengthened with the folding of the roofs, following the edges of the polygon in classrooms and combining: glass, steel, concrete, wood, plasters of colors and whites organizing the space. The floors are of wood, ceramic tile or linoleum extending to the open air with China terrazzo, concrete paving stones and lawn. It is an aggregate of small scale pieces, open by means of patios or terraces, dominating from the main hall of a small community, open and at the same time absorbed within itself. 
ductos: cartón, madera, textil y plásticos, y el carácter de fábrica, que de algún modo recuerda al diseño y producción del Bauhaus. (19) Dominan la fluidez espacial y la luminosidad. El vestíbulo funciona como un patio cubierto con su gran lucernario, pequeñas atalayas con bancos y escaleras. Su extensión en los pasillos crea variedad y dinamismo espacial, potenciado con el plegado de los techos, siguiendo las aristas del polígono en aulas y combinando vidrio, acero, hormigón, madera, revocos de colores y blancos en techos, ordenando el espacio. Los suelos son de madera, gres o linóleo prolongándose al aire libre con terrazo de china, baldosas de hormigón y césped. Es un agregado de piezas de pequeña escala, abiertas mediante patios o terrazas, dominando del aula central de una pequeña comunidad, abierta y a la vez ensimismada.

Epílogo. Los proyectos estudiados ayudan a comprender el método seguido por Scharoun, su Formfindung o búsqueda de la forma específica adecuada a cada función, ensamblada en un conjunto mayor, sin una imagen prefijada y a partir de un proceso abierto incorporando las variables aparecidas en el desarrollo del proyecto. Este concepto de organicidad, surgido como el resultado de una cadena de eventos y decisiones hasta lograr la forma final, parte de unas soluciones descubiertas y ensayadas en los proyectos germinales, evolucionando a lo largo de su obra. El proyecto de Darmstadt es un hito que pasando por los proyectos de escuelas y teatros desembocará en la Filarmónica. Vista de manera global, su obra es asombrosamente coherente, tiene un estilo propio, definido; sus 'inventos' como las geometrías celulares a base de polígonos, sus 'amalgamas espaciales', empleadas como formas fluidas 'en negativo' en los vestíbulos y los espacios urbanos, lo fragmentario frente al formalismo de lo terso y la 'humanización' con el cuidadoso y nada estridente empleo de los materiales y colores, logran la apropiación e identificación del usuario en cada una de las partes de sus edificios-paisaje, que además han demostrado adaptarse a los nuevos planteamientos pedagógicos. Prueba de ello es que ambas escuelas, catalogadas y protegidas, han sido restauradas en los últimos años, Lünen entre 2009 y 2013 y Marl entre 2009 y 2015, después de largas luchas ciudadanas y estudios multidisciplinares que han supuesto un gran desafío técnico.


Fig. 11. Escuela de Marl, entrada y lucernario de los talleres. Johnes, Peter B.: 'Hans Scharoun eine Monografie' (traducción del autor), 1979.

Fig. 12: Escuela de Marl: aula central en los años noventa. Johnes, Peter B.: 'Hans Scharoun', 1995.

Epilogue. The projects studied help to understand the method followed by Scharoun, his Formfindung, or search for the specific form appropriate to each function, assembled into a greater unit, without a prearranged image and beginning with an open process and incorporating the variables which have appeared in the development of the project. This organic quality concept, arising as the result of a chain of events and decisions until it achieves the final form, starts from solutions discovered and tried out in the originative projects and which evolved throughout his work. The Darnstadt project is a milestone which passing through those of schools and theaters will result in the Philharmonie. Viewed globally, his work is astonishingly coherent, with its own defined style; his 'inventions' like the cellular geometries based on polygons, his 'spatial amalgams' used as fluid forms 'in negative' in vestibules and open spaces, the fragmentary as opposed to the formalism of the polished and the 'humanization' with the careful and by no means strident use of materials and colors, attain the appropriation and identification of the user in each one of the parts of his landscape-buildings which furthermore have shown themselves adaptable to the new pedagogical approaches. Proof of this is that both these schools, which are catalogued and protected buildings, have been restored in recent years, Lünen between 2009 and 2013 and Marl between 2009 and 2015, after long citizens' struggles and multidisciplinary studies which have entailed a great technical challenge.

In 1985 Lünen was declared a protected building. Since 1975 it is mixed and has only been out of service during the restauration and energetic renewal works directed by Spital, Frenking \& Schwarz and is an essential reference of German pedagogical reform. A study of reutilization began in 2007, recovering the original image, in spite of the partial repairs 
En 1985 Lünen fue declarada edificio protegido. Desde 1975 es mixta, sólo ha dejado de funcionar durante la obras de restauración y renovación energética dirigidas por Spital, Frenking \& Schwarz, siendo una referencia imprescindible de la reforma pedagógica alemana. En 2007 se inició un estudio de reutilización, recuperando la imagen original, a pesar de las reformas parciales sufridas. El sistema de acondicionamiento original, independizado por aula, que funcionó hasta los años noventa fue fatalmente sustituido por radiadores alterando el comportamiento higrométrico. Ha sido el primer proyecto piloto para "la restauración de arquitecturas modernas de posguerra" de la Fundación Wüstenrot. (20) El proceso de recuperación de Marl ha sido muy largo. Protegida desde 2004 estuvo a punto de ser demolida, fundando los ciudadanos en 2005 el Initiativkreis Scharounschule, o círculo de iniciativas, para influir en las propuestas de recuperación. Finalmente, en 2009 los arquitectos Pfeiffer, Ellermann \& Preckel reciben el encargo de restaurar y reacondicionar el edificio para la Escuela Elemental Católica Aloysius-Grundschule y el Conservatorio Estatal de Música, finalizándose las obras en 2015. Algunas personas, como el antiguo colaborador Michael Hellgard son contrarios a esta segregación de usos que desvirtúa el carácter comunitario inicial que planteaba Scharoun. (21)

Los materiales y las soluciones constructivas originales, por ejemplo en los complicados encuentros en cubierta, desde el principio no funcionaron bien y ambos edificios tuvieron goteras permanentemente, llegando Lünen a tener problemas de condensación con la aparición de hongos en las paredes. Exteriormente, los revestimientos envejecieron mal y nunca hubo dinero ni criterio, especialmente después de la crisis industrial, para llevar el mantenimiento adecuado. Aún así, el aprecio social y actualidad de los espacios, valorado en los documentales por profesores, padres y alumnos, (22) a estos 'otros' edificios modernos, frente al desprecio que he observado en Alemania a las arquitecturas más abstractas de los años sesenta, confirman que la obsesión de Scharoun haciendo edificios 'útiles' a la sociedad que fomentasen los principios democráticos, cívicos y la igualdad de oportunidades, no fueron en vano.

that had taken place. The original conditioning system, independent for each classroom, worked until in the 90's. It was fatally replaced by radiators altering the hygrometric performance. It has been the first pilot project for "the renovation of postwar modern architectures" of the Wüstenrot Foundation. (20) The process of the restoration of Marl has been very long. Protected since 2004, it was on the point of being demolished. In 2005 citizens founded the Initiativkreis Scharounschule or circle of initiatives to have an influence on the restoration proposals. Finally, in 2009 the architects Pfeiffer, Ellermann \& Preckel receive the commission to restore and recondition the building for the Aloysius-Grundschule Elementary Catholic School and the State Conservatory of Music, the works of which were finished in 2015. Some people, such as the former collaborator Michael Hellgard are opposed to this segregation of uses which detracts from the initial community character which Scharoun proposed. (21)

The materials and the original structural solutions, for example, at the complicated points of encounter on the roof, did not work well from the start and both buildings had leaks permanently. Lünen came to have problems of condensation with the appearance of fungi on the walls. On the outside the facings aged badly and there was never money or criteria, especially after the industrial crisis, to keep adequate maintenance. Even so, social appreciation and the up-to date design of spaces, appreciated by teachers parents and pupils, (22) to these 'other' modern buildings as opposed to the disdain which I have observed in Germany towards the more abstract architectures of the 60's, confirm that Scharoun's obsession for making 'useful' buildings for society and which should promote democratic and civil principles and equality of opportunity, were not in vain. 


\section{NOTAS}

1. Comentario de Scharoun a la reducción del programa en Marl. Entrevista Michael Hellgard. 'Von der Volkschule zum Schludorf'.

2. BARTNING, Otto (ed.). Mensch und Raum. Das Darmstädter Gespräch, 1951. Bauwelt-Fundamente 94. Braunschweig: Vieweg, 1991. p. 172.

3. Opus cit. pp. 88-131.

4. Ibidem. pp. 132-168.

5. Hans Scharoun Archive. Colaboradores: Karl Böttcher, Chen Kuen Lee, Sergius Ruegenberg, Wilhelm Seemann y Alfred Schinz. Fotógrafo: Ewald Gnilka.

6. SCHIRREN, Mathias. 'Wind und Wasser, Raum und Zeit. Der Darmstädter Schulentwurf im Werk von Hans Scharoun'. Zaeb.net. Schularchitektur und ästhetische Bildung. 2014, Jg. 6, n. 1. pp. 4-21.

7. J. M. Olbricht, discípulo de C. Sitte, autor de la Matildenhöhe siendo P. Behrens colaborador y cofundador del Deustscher Werkbund.

8. María Schwarz. Ver: SCHIRREN, Matthias. Opus cit.p. 2.

9. Ibidem. p. 5, nota 5. M.S. alude al comentario de P. Bonatz la conferencia.

En: Mensch und Raum. Opus cit. p. 91.

10. SCHAROUN, Hans. 'Raum und Milieu der Schule'. Conferencia en la XII

Trienale. Bauen+Wohnen, n. 4, 1961.p. IV/4.

11. El estanque aparece como un patio interior en la planta publicada por

JOHNES, Peter B. Opus cit. p. 17. No se menciona en el texto. Comprobado en el archivo de la Akademie, junio de 2017.

12. Opus cit. p. 11, fig. 11.

13. 'Nachbarschaft' como unas células diferenciadas que integran la estructura de un organismo y sus principios de relación recíproca. Ver: SCHIRREN, M. Opus cit. p. 12.

14. En los años cincuenta las tasas de abandono escolar eran altísimas. El paso de la escuela elemental al Bachillerato (Gymnasium) era apenas del $12,5 \%$. Los objetivos de Scharoun eran totalmente ideales. Ver: 'El sistema educativo en la República Federal de Alemania (III)'. Revista de Educación, n. 298. Madrid: MECD, 1992. pp. 394-436.

15. Proyecto utópico, realizable según su promotor K. E. Osthaus. Ver GARCIA ROIG, José Manuel. 'Pensamiento Utópico, Germanidad y arquitectura. Karl Ernst Osthaus y Bruno Taut. Cuaderno de Notas, n. 7. Madrid: DCA ETSAM, 2011. pp. 97-109.

16. SHIRREN, M. Opus cit. p. 8.

17. Opus cit. n. 27. p. 16. Según M.S. El libro Baukunst de E. Boermann influye en la 'sala cósmica'. El sol no se dibuja como una esfera, sino a partir de su reflejo en los otros tres elementos y ello es también una forma de representación del paso del tiempo.

18. HELLGARDT, Michael. 'Scharounschule Marl-eine Anregung zur künftige Nutzung im Sinne Scharouns' Deutscher Werkbund Nordrhein Westfalen, 2012. p. 5.

19. Proponía que los talleres sirvieran para las escuelas vecinas. El Bauhaus, el Expresionismo y las utopías de Taut o la relación de Kandisnky y Klee con la antroposofía: la escuela sería una síntesis de estas ideas.

20. Ver: BRINKMANN, Ulrich. 'Gutachten zur Sanierung der GeschwisterScholl-Schule von Hans Scharoun in Lünen: Spital, Frenking \& Schwarz'. Bauwelt, n. 8. Gütersloh: Bauverlag GmbH, 2008. pp. 32-37.

21. Ver: Opus cit. p. 3. Un extenso informe de todo el proceso en: Die Scharounschule Marl. Ein Meisterwerk der Moderne. Marl: BürgermeisteramtKommunikation \& Medien, 2015. p. 28.

22. 'Wiedereröffnung der Scharoun-Schule'. Medienhaus Bauer. Comentarios de la jefa de estudios Roswita Schweinsberg. Disponible en: [https://www. youtube.com/watch? $=\mathbf{x w C} \_$ahps_78].
NOTES

1. Scharoun's remark on the Marl program reduction. Interview Michael Hellgard. 'Von der Volkschule zum Schludorf'.

2. BARTNING, Otto (ed.). Mensch und Raum. Das Darmstädter Gespräch, 1951. Bauwelt-Fundamente 94. Braunschweig: Vieweg, 1991. p. 172.

3. Opus cit. pp. 88-131.

4. Ibidem. pp. 132-168.

5. Hans Scharoun Archive. Colaborators: Karl Böttcher, Chen Kuen Lee, Sergius Ruegenberg, Wilhelm Seemann y Alfred Schinz. Photographer: Ewald Gnilka.

6. SCHIRREN, Mathias. 'Wind und Wasser, Raum und Zeit. Der Darmstädter Schulentwurf im Werk von Hans Scharoun'. Zaeb.net. Schularchitektur und ästhetische Bildung. 2014, Jg. 6, n. 1. pp. 4-2.

7. J. M. Olbricht, disciple of C. Sitte, author of Matildenhöhe with P. Behrens collaborating and co-founder of Deustscher Werkbund.

8. María Schwarz. See: SCHIRREN, Matthias. Opus cit. p. 2.

9. Ibidem. p. 5, note 5. M.S. alludes to P. Bonatz's comment in his lecture. In: Mensch und Raum. Opus cit. p. 91.

10. SCHAROUN, H. 'Raum und Milieu der Schule'. Lecture XII Trienale, 1961, n. 4. p. IV/4.

11. The pond appears as an inner courtyard on the plan published by JOHNES, Peter B. Opus cit. p. 17. Not mentioned in the text. Checked at the Akademie Archives, June 2017.

12. Opus cit. p. 11, fig. 11.

13. 'Nachbarschaft' as differentiated cells that integrate the structure of an organism and its principles of reciprocal relationship. See: SCHIRREN, M. Opus cit.p. 12.

14. In the $1950 \mathrm{~s}$, school dropout rates were very high. The transition from elementary to High School (Gymnasium) was barely $12.5 \%$. Scharoun's objectives were totally ideal. See: 'El sistema educativo en la República Federal de Alemania (III)'. Revista de Educación, n. 298. Madrid: MECD, 1992. pp. 394-436.

15. Utopical project, possible according to its promoter K. E. Osthaus. GARCIA ROIG, José Manuel. 'Pensamiento Utópico, Germanidad y arquitectura. Karl Ernst Osthaus y Bruno Taut'. Cuaderno de Notas, n. 7. Madrid: DCA ETSAM, 2011. pp. 97-109.

16. SHIRREN, M. Opus cit. p. 8.

17. Opus cit, n. 27. p.16. According to M.S. E. Boermann's book Baukunst influences the 'cosmic hall'. The sun is not drawn as a sphere, but from its reflection in the other three elements and this is also a form of representation of the passage of time.

18. HELLGARDT, Michael. 'Scharounschule Marl-eine Anregung zur künftige Nutzung im Sinne Scharouns'. Deutscher Werkbund Nordrhein Westfalen, 2012. p. 5 .

19. He proposed that the workshops might serve neighboring schools. The Bauhaus, Expressionism and the utopias of Taut or the relationship of Kandisnky and Klee with anthroposophy: the school would be a synthesis of all those ideas.

20. See: ULRICH. 'Gutachten zur Sanierung der Geschwister-Scholl-Schule von Hans Scharoun in Lünen: Spital, Frenking \& Schwarz'. Bauwelt, n. 8. Gütersloh: Bauverlag GmbH, 2008. pp. 32-37.

21. See: Opus cit. p, 3. An extensive report of the entire process in: Die Scharounschule Marl. Ein Meisterwerk der Moderne. Marl: Bürgermeisteramt-Kommunikation \& Medien, 2015. p. 28.

22. 'Wiedereröffnung der Scharoun-Schule'. Medienhaus Bauer. Comments from head of studies Roswita Schweinsberg. Available at[ https://www. youtube.com/watch? $\left.=x w C \_a h p s \_78\right]$. 


\section{REFERENCIAS}

BARTNING, Otto (ed.). Mensch und Raum. Das Darmstädter Gespräch, 1951. Bauwelt-Fundamente 94. Braunschweig: Vieweg, 1991.

BRINKMANN, Ulrich. 'Gutachten zur Sanierung der Geschwister-SchollSchule von Hans Scharoun in Lünen: Spital, Frenking \& Schwarz'. Bauwelt, n. 8. Gütersloh: Bauverlag GmbH, 2008.

GARCIA ROIG, José Manuel. 'Pensamiento Utópico, Germanidad y arquitectura. Karl Ernst Osthaus y Bruno Taut'. Cuaderno de Notas, n. 7. Madrid: DCA ETSAM, 2011.

HELLGARDT, Michael. 'Scharounschule Marl-eine Anregung zur künftige Nutzung im Sinne Scharouns. Deutscher Werkbund Nordrhein Westfalen, 2012.

HELLGARDT, Michael. 'Von der Volkschule zum Schludorf. Die Scharounschule Marl. Ein Meisterwerk der Moderne. Marl: Bürgermeisteramt-Kommunikation \& Medien, 2015.

JOHNES, Peter B. Hans Scharoun. Eine Monographie. Stuttgart: Krämer, 1979.

JOHNES, Peter B. Hans Scharoun. Londres: Phaidon, 1995.

SCHAROUN, Hans. 'Raum und Milieu der Schule'. Conferencia en la XII Trienale. Bauen+Wohnen, n. 4, 1961.

SCHIRREN, Matthias. 'Wind und Wasser, Raum und Zeit. Der Darmstädter Schulentwurf im Werk von Hans Scharoun' Zaeb.net. Schularchitektur und ästhetische Bildung. 2014, Jg. 6, n. 1. Disponible en: [http://archiv.zaeb.net/ index.php/zaeb/article/view/77/77].

U.S.E. 'Wir bauen,weil wir unzufrieden sind. (Construimos porque estamos insatisfechos). Die Zeit. Hamburgo: 9 de agosto, 1951.

'El sistema educativo en la República Federal de Alemania (III)'. Revista de Educación, n. 298. Madrid: MECD, 1992.

Die Scharounschule Marl. Ein Meisterwerk der Moderne. Marl: Bürgermeisteramt-Kommunikation \& Medien, 2015. p. 28.
REFERENCES

BARTNING, Otto (ed.).Mensch und Raum. Das Darmstädter Gespräch,

1951. Bauwelt-Fundamente 94. Braunschweig: Vieweg, 1991.

BRINKMANN, Ulrich. 'Gutachten zur Sanierung der Geschwister-Scholl-

Schule von Hans Scharoun in Lünen: Spital, Frenking \& Schwarz. Bauwelt, n. 8. Gütersloh: Bauverlag GmbH, 2008.

GARCIA ROIG, José Manuel. 'Pensamiento Utópico, Germanidad y arquitectura. Karl Ernst Osthaus y Bruno Taut'. Cuaderno de Notas, n. 7. Madrid: DCA ETSAM, 2011.

HELLGARDT, Michael. 'Scharounschule Marl-eine Anregung zur künftige Nutzung im Sinne Scharouns'. Deutscher Werkbund Nordrhein Westfalen, 2012.

HELLGARDT, Michael. 'Von der Volkschule zum Schludorf. Die Scharounschule Marl. Ein Meisterwerk der Moderne. Marl: Bürgermeisteramt-Kommunikation \& Medien, 2015.

JOHNES, Peter B. Hans Scharoun. Ei

1979.

JOHNES, Peter B. Hans Scharoun. London: Phaidon, 1995.

SCHAROUN, Hans. 'Raum und Milie: de

Trienale. Bauen+Wohnen, n.4.1961.

SCHIRREN, Matthias. 'Wind und Wasser, Raum ut

Schulentwurf im Werk von Hans Scharoun'.Zaeb, index.php/zaeb/article/view/77/77].

U.S.E. 'Wir bauen, weil wir unzufrieden sind. (Construimos porque estamos insatisfechos). Die Zeit. Hamburg: August 9th, 1951.

'El sistema educativo en la República Federal deAlemania (III)'. Re Educación, n. 298. Madrid: MECD, 1992.

Die Scharounschule Marl. Ein Meisterwerk der Moderne. Mäl: Bürgermeisteramt-Kommunikation \& Medien, 2015
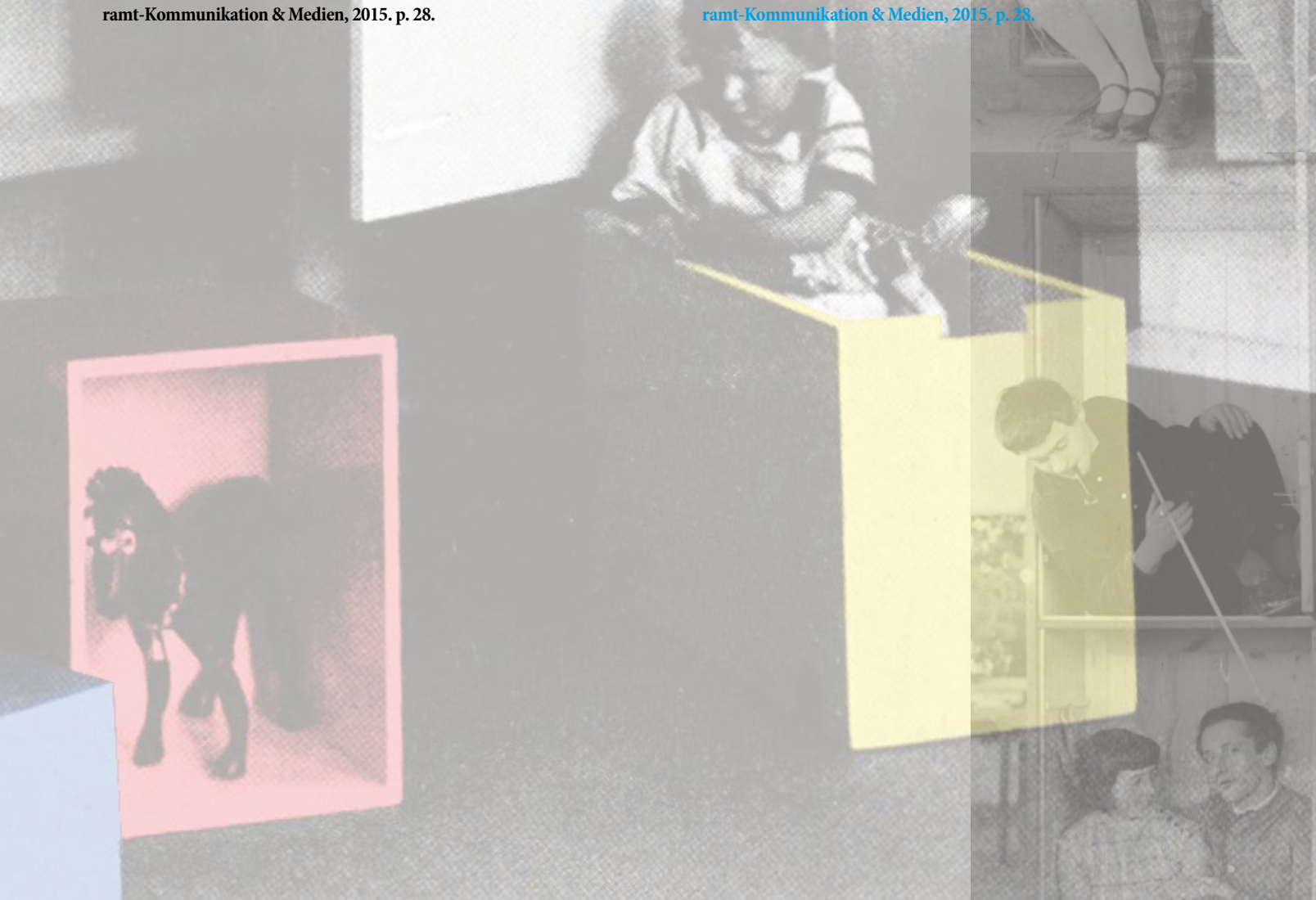

Alma Buscher

Spielschrank mit Schranktür für Kasperletheater und Bewegliche Kästen

(Armario de juegos con puerta para teatro de títeres y cajas móviles) 